\title{
Acute or chronic pulmonary emphysema? Or both?-A contribution to the diagnosis of death due to violent asphyxiation in cases with pre-existing chronic emphysema
}

\author{
Giuseppe Gava ${ }^{1} \cdot$ Simon B. Eickhoff ${ }^{2,3} \cdot$ Timm J. Filler $^{4}$ (D) Felix Mayer $^{1} \cdot$ Nina S. Mahlke $^{1}$ (D) Stefanie Ritz-Timme ${ }^{1}$
}

Received: 28 December 2020 / Accepted: 30 April 2021 / Published online: 28 June 2021

(c) The Author(s) 2021

\begin{abstract}
The diagnosis of death due to violent asphyxiation may be challenging if external injuries are missing, and a typical acute emphysema (AE) "disappears" in pre-existing chronic emphysema (CE). Eighty-four autopsy cases were systematically investigated to identify a (histo-) morphological or immunohistochemical marker combination that enables the diagnosis of violent asphyxiation in cases with a pre-existing CE ("AE in CE"). The cases comprised four diagnostic groups, namely "AE", "CE", "acute and chronic emphysema (AE + CE)", and "no emphysema (NE)". Samples from all pulmonary lobes were investigated by conventional histological methods as well as with the immunohistochemical markers Aquaporin 5 (AQP-5) and Surfactant protein A1 (SP-A). Particular attention was paid to alveolar septum ends ("dead-ends") suspected as rupture spots, which were additionally analyzed by transmission electron microscopy. The findings in the four diagnostic groups were compared using multivariate analysis and 1-way ANOVA analysis. All morphological findings were found in all four groups. Based on histological and macroscopic findings, a multivariate analysis was able to predict the correct diagnosis "AE + CE" with a probability of 50\%, and the diagnoses "AE" and "CE" with a probability of $86 \%$ each. Three types of "dead-ends" could be differentiated. One type ("fringed ends") was observed significantly more frequently in AE. The immunohistochemical markers AQP-5 and SP-A did not show significant differences among the examined groups. Though a reliable identification of $\mathrm{AE}$ in $\mathrm{CE}$ could not be achieved using the examined parameters, our findings suggest that considering many different findings from the macroscopical, histomorphological, and molecular level by multivariate analysis is an approach that should be followed.
\end{abstract}

Keywords Acute versus chronic pulmonary emphysema - Violent asphyxiation · Aquaporin $5 \cdot$ Surfactant protein A1 . Transmission electron microscopy

Nina S. Mahlke and Stefanie Ritz-Timme have shared senior authorship

Nina S. Mahlke

ninasophia.mahlke@med.uni-duesseldorf.de

1 Institute of Legal Medicine, Heinrich Heine University Düsseldorf, Düsseldorf, Germany

2 Institute of Systems Neuroscience, Medical Faculty, Heinrich Heine University Düsseldorf, Düsseldorf, Germany

3 Institute of Neuroscience and Medicine, Brain \& Behaviour (INM-7), Research Centre Jülich, Jülich, Germany

4 Institute for Anatomy I, Heinrich Heine University Düsseldorf, Düsseldorf, Germany

\section{Introduction}

Death by violent asphyxia can be caused by various mechanisms (e.g., strangulation, covering of the external airways), which may cause typical findings. Such findings may include external and internal signs of violence, the so-called congestion syndrome (with petechial hemorrhages) as well as acute emphysema (AE); in addition, there may be further external injuries, such as holding, defense, and/or counter-pressure injuries [1-7].

However, the pattern of findings may also be very discrete. This might be especially the case if the victim was unable to defend him- or herself (e.g., in cases of physical superiority of the offender, intoxication of the victim, or physically frail victims like children or elderly [7-11]). Other reasons for missing skin or tissue findings, like 
hematoma or hemorrhages, may be very smooth, soft strangulation tools, or wearing gloves. Other problematic examples are cases of burking (a combination of covered airways and thorax compression $[5,12,13])$ or deaths due to physical restraint [14]. In such cases, the suspicion of violent death can only be substantiated by internal postmortem findings and histological examination [15-22]; otherwise, it becomes a diagnosis by exclusion $[7,17,23]$. Generally, it has to be noted that the many common findings are only typical, but not specific for violent asphyxiation $[3,4,24,25]$ and may also occur with other causes of death.

Much research has focused on the pulmonary findings. Brinkmann et al. described a specific combination of emphysema, microembolism syndrome, alveolar septal edema, and hemorrhagic-dysoric syndrome as "pathognomonic of obstructive asphyxia" [17]. However, this conclusion was refuted by other authors, since this constellation of findings was also found in control groups, e.g., in cases of shock or resuscitation [26, 27]. Several studies on human lung tissue described a significant increase in alveolar macrophages and giant cells, especially in protracted asphyxia [10, 28-31]. Betz et al. [32, 33] and Grellner et al. [34], conversely, described in their studies that there is no significant giant cell formation or alveolar macrophage proliferation in deaths by asphyxia, which could also be substantiated in 2019 by Gutjahr et al. [27, 35] ("pre-existence hypothesis"). The agony times in these studies correspond to the "realistic" times in the cases of asphyxiation in everyday forensic medicine.

A very relevant pulmonary finding is the acute pulmonary emphysema or acute alveolar dilation, respectively $[3,5]$. In some cases, an interstitial emphysema is described $[6,36]$. There are only a few differential diagnoses to be considered (e.g., resuscitation or mechanical ventilation [37], severe asthma [38]), which in most cases can be easily excluded by the patient's history. In young, primarily healthy people, it can usually be clearly diagnosed by macroscopical and histological examination. However, diagnostic problems regularly arise in patients with pre-existing chronic emphysema (CE) $[39,40]$. In these cases, the AE may be "overlayed" and cannot be distinguished anymore, especially in collapsed lungs after regular autopsy [41]. There is currently no diagnostic marker or morphological finding that enables the diagnosis of "AE in CE". Many studies on the diagnosis of violent asphyxiation did not include or explicitly exclude cases of $\mathrm{CE}$ or $\mathrm{AE}+\mathrm{CE}[42-51]$.

Regarding the significantly different pathomechanisms of the development of $\mathrm{AE}$ and $\mathrm{CE}$, the identification of "AE in CE" should be possible. While AE develops within minutes due to sudden mechanical stress [1,52], chronic emphysema develops over several years due to a variety of causes (e.g., senile emphysema [53-55], chronic obstructive pulmonary disease (COPD) [56], alpha-1-antitrypsin deficiency [57], or other secondary forms [58]). Whereas asphyxiation leads to acute hyperinflation and acute ruptures in the alveolar septums, remodelling processes in the elastin and collagen structure have already occurred in chronic emphysema [59-61].

Against this background, 84 autopsy cases in four diagnostic groups ("AE", "CE", "AE + CE", "NE" (no emphysema)) were systematically investigated to identify a specific histomorphological or macroscopical constellation of findings or an immunohistochemical pattern that enables the diagnosis "AE in CE". Samples from all pulmonary lobes were investigated by conventional histological methods (hematoxylin-eosin, Elastica-van-Gieson, and iron staining) as well as with immunohistochemical markers Aquaporin 5 (AQP-5) and Surfactant protein A1 (SP-A) that have been described as being significantly differentially expressed in the lungs of asphyxiation victims than in other causes of death [42-51, 62]. Particular attention was paid to alveolar septum ends ("dead-ends") suspected as rupture spots. These were additionally analyzed by transmission electron microscopy (TEM). The histomorphological and macroscopical findings in the four diagnostic groups were compared and evaluated by a multivariate approach, based on machine learning. Importantly, evaluation of the models was performed by out-of-sample prediction, that is, we assessed, how accurately the model could predict the different diagnoses in new, previously unseen cases, i.e., in subjects that have not been part of the training set. The AQP-5 and SP-A results were assessed separately.

\section{Material and methods}

\section{Case selection, autopsy specimens, and macroscopical findings}

All cases were retrospectively selected by checking the autopsy reports of the Institute of Legal Medicine in Duesseldorf (Germany). A total of 84 cases (51 male and 33 female individuals with ages between 1 day and 90 years) were selected based on previous history, police investigations, and reported macroscopic findings, and divided into four groups according to the diagnosis of pulmonary emphysema. The groups were "acute emphysema $=\mathrm{AE}$ " $(n=22)$, "chronic emphysema $=$ CE" $(n=43)$, "acute + chronic emphysema $=\mathrm{AE}+\mathrm{CE}$ " $(n=12)$, and "no emphysema $=\mathrm{NE}$ " $(n=7)$. We categorized our cases primarily according to the form of emphysema and did not further subdivide the groups according to the forms of asphyxia since we wanted to address the situation "suspected asphyxiation/suffocation, discrete external findings, unclear course of events". Individuals with evidence of violent asphyxiation or resuscitation and a clear emphysema without any indication of 
pre-existing emphysema were assigned to the "AE" group. Individuals with evidence of pre-existing emphysema (e.g., known COPD) or macroscopically visible pulmonary hyperinflation (e.g., due to senile emphysema, which is often an incidental finding), but without clues for violent asphyxiation or resuscitation, were assigned to the "CE" group. The group "AE $+\mathrm{CE}$ " comprised individuals with described pre-existing $\mathrm{CE}$ and assumed $\mathrm{AE}$ due to the cause of death (asphyxiation) that was based on other findings (e.g., external injuries) and case history. Individuals without pathological lung changes were assigned to the "NE" group. Exclusion criteria were signs of advanced putrefaction or severe lung diseases (other than chronic emphysema) such as pneumonia or tumors. Since acute emphysema can also occur during resuscitation with artificial ventilation [37], we included these cases in the "AE" group. A performed resuscitation was also not an exclusion criterion in the "AE + CE" group; however, this did not occur in our cases. The delay between the time of death and performing autopsy varied between 0 and 17 days. In 21 cases, the exact interval was unknown.

For each case, the macroscopical findings documented in the autopsy protocols were assessed and coded in numbers for statistical analysis, as shown in Table 1.

\section{Lung tissue samples}

A peripheral sample from each upper and lower lung lobe and a central sample from the right middle lobe was taken. They were stored in $4 \%$ phosphate-buffered formaldehyde solution at room temperature. For light microscopic and immunohistochemical staining, they were further embedded in paraffin and sliced into $2 \mu \mathrm{m}$ thick sections and then stored at room temperature until staining (see below). For electron microscopic preparation, see below.

\section{Conventional histology}

The specimens from all lung lobes were stained according to standard protocols for hematoxylin-eosin (H\&E) and Elastica-van-Gieson (EvG) [63]. The right lower lobe was additionally stained in Berlin blue iron staining $(\mathrm{Fe})$ to distinguish hemosiderin-containing macrophages (siderophages), which are an indirect sign of chronic heart failure [64], from regular alveolar macrophages. Histological findings that were described as typical for violent asphyxia [20, 21, 26] were recorded in a standardized form. In addition, we evaluated and classified the blind-ending alveolar septal ends, which we have called "dead-ends". When examining the lung specimens, we deliberately decided against screening them according to strictly defined, side-by-side visual fields in the specimen, since it can occur that a large part of the observed area consists only of an atelectasis, an emphysema bubble (bulla), a large (central) vessel, or some other largescale change. To get an initial overview of the specimen, we first viewed it at a low magnification $(\times 40)$. Then, at a higher magnification $(\times 200-400)$, we examined the "representative" areas of the specimen, i.e., those without the above-mentioned changes. We documented the findings as shown in Table 2 . The specimens were assessed separately by two examiners.

\section{Immunohistochemistry}

We used the following polyclonal primary antibodies for immunohistochemistry (IHC):

- Aquaporin 5 (AQP-5), rabbit (ABIN731260, obtained via www.antibodies-online.com)

- Surfactant Protein A1 (SP-A), rabbit (ABIN3187728, obtained via www.antibodies-online.com)

For AQP-5 staining, we selected specimens from the right upper or lower lobe that showed a preserved bronchial epithelium in H\&E staining for internal positive control, resulting in a total of 43 cases (18 "AE", 11 "CE", 8 "AE + CE", and 6 "NE"). For SP-A, we used the right upper and lower lobe from 78 cases (18 "AE", 42 "CE", 11 "AE + CE", and 7 "NE"). Cases in which the AE was probably only caused by resuscitation procedures were excluded because the changes described in the literature were only described for death by asphyxia and not for acute emphysema alone.

The sections were dewaxed with xylene and a descending alcohol series before rehydrating them in distilled water. Afterwards, we demasked the epitopes by incubating them in citrate buffer ( $\mathrm{pH}$ 6.0) for $45 \mathrm{~min}$ in a steam cooker. For staining, they were first incubated in peroxidase block solution (Cell Marque ${ }^{\mathrm{TM}}$ ) for $10 \mathrm{~min}$. Then, 300-fold diluted primary antibody solution was added $(200 \mu \mathrm{L}$ on every section), and the samples were incubated at $4{ }^{\circ} \mathrm{C}$ in the humidity chamber overnight. Then, the secondary antibody (Histofine ${ }^{\circledR}$ Simple Stain MAX PO) was added, followed by incubation of $30 \mathrm{~min}$. The AQP-5 sections were incubated in DAB (3,3'-diaminobenzidine) chromogen for $10 \mathrm{~min}$ and the SP-A sections in AEC (3-amino-9-ethylcarbazole) chromogen for $15 \mathrm{~min}$, respectively. After every incubation, the samples were washed three times in TBST (Tris-buffered saline with Tween $\left.{ }^{\circledR}\right)$ buffer. Finally, they were counterstained with hematoxylin for about $20 \mathrm{~s}$ before covering them with Aquatex ${ }^{\circledR}$. As positive controls, we used human kidney specimens from one of our autopsy cases for both primary antibodies. Negative controls for each slide were processed according to the described staining protocol without adding the primary antibodies.

The AQP-5 immunoreactivity in the bronchial epithelium was assessed as follows: negative ( - ), weakly positive $(+)$, 


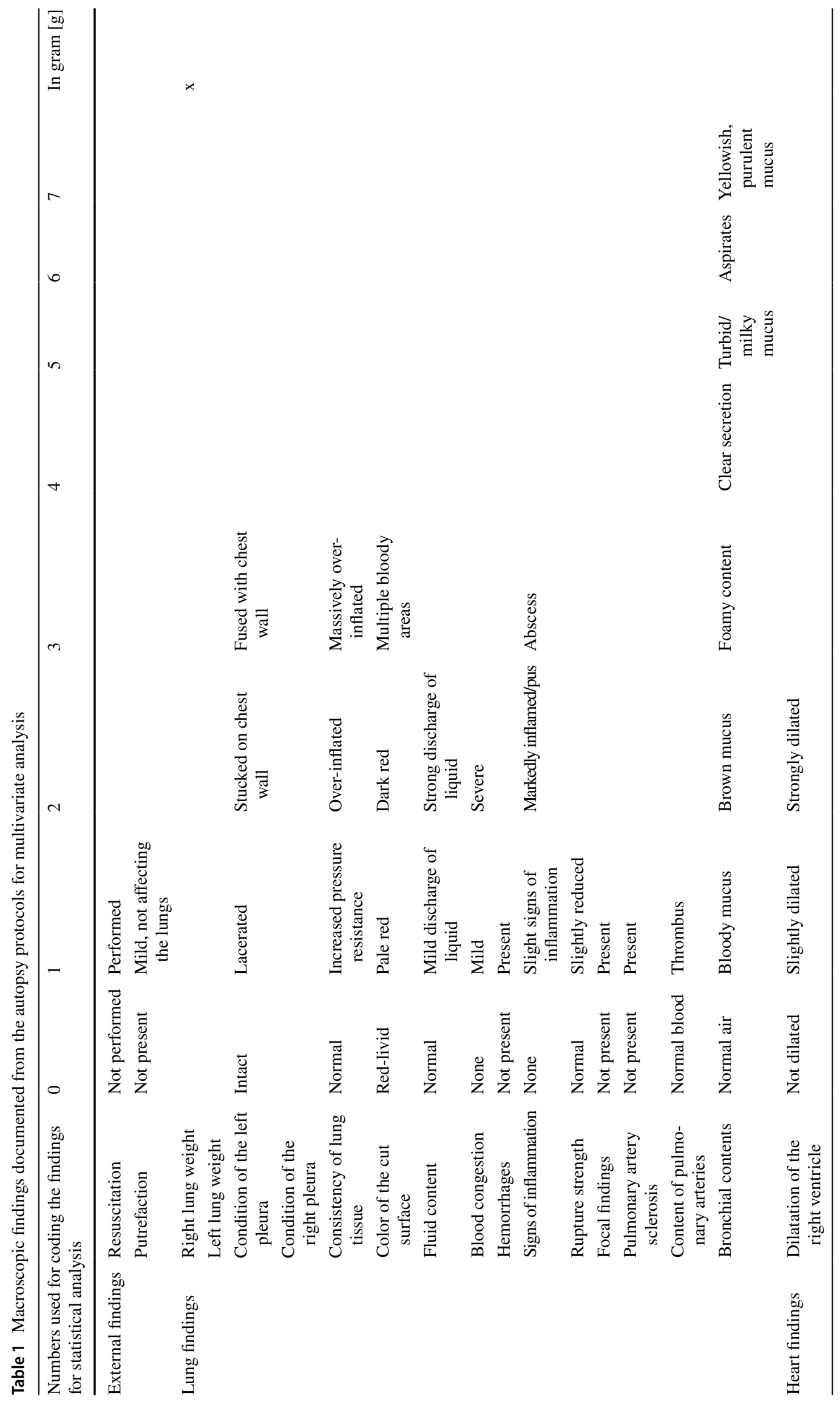


Table 2 Histological findings. In hematoxylin-eosin stained sections, all shown findings except the siderophages were assessed semi-quantitatively in the entire specimen. Particularities were documented qualitatively. In Elastica-vanGieson stained sections only the "dead-ends" and particularities were documented, and in the Berlin blue stained sections only the siderophages and particularities

\begin{tabular}{|c|c|c|c|c|c|c|}
\hline & & \multicolumn{4}{|c|}{ semi-quantitative } & \multirow{2}{*}{$\begin{array}{l}\text { quali- } \\
\text { tatively } \\
\text { assessed }\end{array}$} \\
\hline & & - & + & ++ & +++ & \\
\hline Atelectasis & & none & mild & severe & & \\
\hline Alveolar dilatation & & none & mild & severe & & \\
\hline \multirow[t]{3}{*}{ Edema } & interstitial & none & mild & severe & & \\
\hline & alveolar & none & mild & severe & & \\
\hline & alveolar & none & mild & severe & & \\
\hline \multirow[t]{3}{*}{ Hemorrhages } & interstitial & none & mild & severe & & \\
\hline & periarterial & none & mild & severe & & \\
\hline & peribronchial & none & mild & severe & & \\
\hline Hyperemia & & none & mild & severe & & \\
\hline Alveolar macrophages & & none & few & many & many in clusters & \\
\hline Siderophages & & none & few & many & many in clusters & \\
\hline \multirow[t]{3}{*}{ Dead-ends } & smooth & none & few & many & & \\
\hline & fringed & none & few & many & & \\
\hline & drumstick-like & none & few & many & & \\
\hline Pulmonary artery sclerosis & & not present & present & & & \\
\hline Pathological vessel content & & not present & present & & & \\
\hline Particularities & & & & & & \\
\hline
\end{tabular}

and strongly positive $(++)$. The findings in pneumocytes type I cells were negative $(-)$, some single cells positive $(+)$, and positive with a linear pattern $(++)$.

For the evaluation of SP-A immunostaining, we used the same classification according to Zhu et al. [44, 65]. Pneumocytes type II cells and alveolar surface (membranous or linear pattern): negative $(-)$, weakly positive $(+)$, diffusely, and clearly positive $(++)$, and strongly positive $(+++)$. Intra-alveolar SP-A aggregates (granular pattern): negative $(-)$, a few aggregates in some alveoli $(+)$, some bigger aggregates in some alveoli $(++)$, and many massive aggregates in almost all alveoli $(+++)$. We always documented the findings for those areas that showed the strongest pattern. The specimens were also assessed separately by two examiners.

\section{Transmission electron microscopy}

The formalin-fixed tissue from six "AE" and five "CE" cases was refixed overnight in $4 \%$ glutaraldehyde (GA) in phosphate-buffered saline (PBS) buffer at $4{ }^{\circ} \mathrm{C}$. One lung tissue sample taken prospectively during another autopsy was directly fixed in conventional EM-fixans (2.5\% GA, $4 \%$ paraformaldehyde in $0.1 \mathrm{M}$ cacodylate buffer, $\mathrm{pH}$ 7.4) to compare the image quality between the two methods. $3 \times 3 \mathrm{~mm}$ cube-shaped specimens were cut out manually for further processing. They were incubated in a $1 \%$ osmium tetroxide solution in PBS or $0.1 \mathrm{M}$ cacodylate buffer respectively for $2 \mathrm{~h}$ and rinsed in aqua dest before dehydrating them in acetone $(30 \%, 50 \%, 70 \%, 90 \%$, and $100 \%)$. While dehydration in $70 \%$ acetone, block contrast was applied (1\% phosphotungstic acid $/ 0.5 \%$ uranyl acetate in $70 \%$ acetone). Further SPURR embedding medium (Serva, Heidelberg, Germany) was used to embed samples which were then polymerized overnight at $70{ }^{\circ} \mathrm{C}$. We produced $1 \mu \mathrm{m}$ semi-thin sections and stained them in toluidine blue to search the alveolar septal segments of our interest for further ultrastructural investigation. After this, the samples were cut into $70 \mathrm{~nm}$ thin slices by using an Ultracut EM UC7 (Leica Microsystems GmbH, Wetzlar, Germany) and stained with lead-citrate (according to Reynolds [66]) for $8 \mathrm{~min}$ and $1.5 \%$ uranyl acetate for $25 \mathrm{~min}$. Images were captured using an H-7100 TEM (Hitachi, Tokyo, Japan) at $100 \mathrm{kV}$ and a Morada SIS Camera system; they were subsequently processed by the Olympus ITEM 5.0 Software.

\section{Statistical analysis and establishment of a multivariate analysis}

The macroscopic autopsy findings and the histological findings recorded in the standardized form were analyzed using multivariate pattern recognition. This approach builds a model predicting individual diagnosis on the training sample that is then applied to the previously unseen test data. In more detail, we considered the information from macroand microscopy as the features on which a classification algorithm is trained to predict the diagnosis, i.e., the results of the autopsy, serving as the target variable. As learning the relationships between features and targets obviously requires known diagnoses, the ability of the thus trained 
algorithms to correctly diagnose new subjects needs to be tested on new cases for which the model is provided with only the features and the ensuing diagnosis is then evaluated against the known (to us but not the algorithm) true diagnosis. Here we performed such evaluation by a standard leave-one-out approach, i.e., each individual case was subsequently removed from the data before the model was trained on the remaining cases. The trained model is then applied to the features of the held-out subject and the decision recorded. For the actual prediction model, we employed boosted decision trees, as a widely used ensemble model incrementally aggregating binary decision trees by focussing each new iteration on those instances (within the training sample) that were previously miss-classified. Here, we used the implementation within Matlab R2020a with the following settings: total boost algorithm, maximum of 6 splits per tree, margin precision 0.005 .

The mean occurrence of the dead-ends in EvG sections and alveolar macrophages and the mean expression of the SP-A patterns were separately evaluated in a 1-way ANOVA analysis and presented as boxplots. $p$-values $<0.05$, corrected for multiple comparisons using the false discovery rate (FDR), were considered significant.

\section{Results}

\section{Multivariate analysis from macroscopic and conventional histological pulmonary findings}

All conventional histological findings (described as typical pulmonary findings for violent asphyxia in the literature, see Table 2) could be observed in our cases, although to varying extents.

Our multivariate model derived from all conventional histological and macroscopic findings was able to correctly predict the correct clinical diagnoses in new cases, i.e., those that have not been seen during training with an accuracy of 0.79 (balanced accuracy 0.7, F1-Score 0.82).

In detail, the different diagnoses could be predicted with the following probabilities (Fig. 1):

- $86 \%$ probability for a correct classification of "AE" cases as "AE" cases

- $86 \%$ probability for a correct classification of "CE" cases as "CE" cases

- $57 \%$ probability for a correct classification of "NE" cases as "NE" cases

- $50 \%$ probability for a correct classification of "AE + CE" cases as "AE + CE" cases

- $50 \%$ probability for a false classification of "AE + CE" cases as "CE" cases

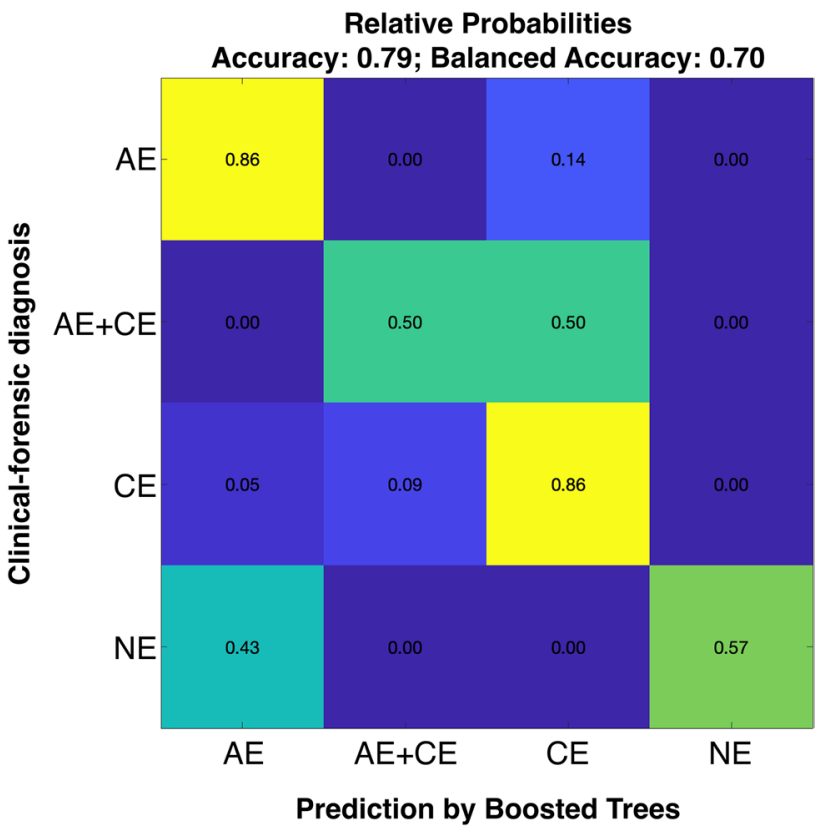

Fig. 1 Results of the multivariate analysis including all light microscopic and macroscopic findings. Prediction probabilities (numbers in the boxes) denoting how likely a given clinical-forensic diagnosis was assigned correctly to a particular label in the algorithm evaluation (Accuracy $=$ number of correctly classified cases / all cases, Balanced Accuracy: mean accuracy for each individual diagnostic group, $\mathrm{AE}=$ acute emphysema, $\mathrm{CE}=$ chronic emphysema, $\mathrm{AE}+\mathrm{CE}=$ acute and chronic emphysema, $\mathrm{NE}=$ no emphysema)

- $43 \%$ probability for a false classification of "NE" cases as "AE" cases

- $14 \%$ probability for a false classification of "AE" cases as "CE" cases

- $9 \%$ probability for a false classification of "CE" cases as "AE + CE" cases

- $5 \%$ probability for a false classification of "CE" cases as "AE" cases

- Each 0\% probability for a false classification of "AE" cases as "AE + CE" cases, "AE" cases as "NE" cases, "AE + CE" cases as "AE" cases, "AE + CE" cases as "NE" cases, "CE" cases as "NE" cases, "NE" cases as "AE + CE" cases, and "NE" cases as "CE" cases, respectively.

\section{Special histological findings}

Three types of dead-ends (Fig. 2) could be identified:

- "Drumstick-like" dead-ends with a pronounced rounded thickening at the tip

- "Fringed" dead-ends with an irregularly shaped tip, appearing destroyed

- "Smooth" dead-ends with a smooth and continuously membrane-covered tip 


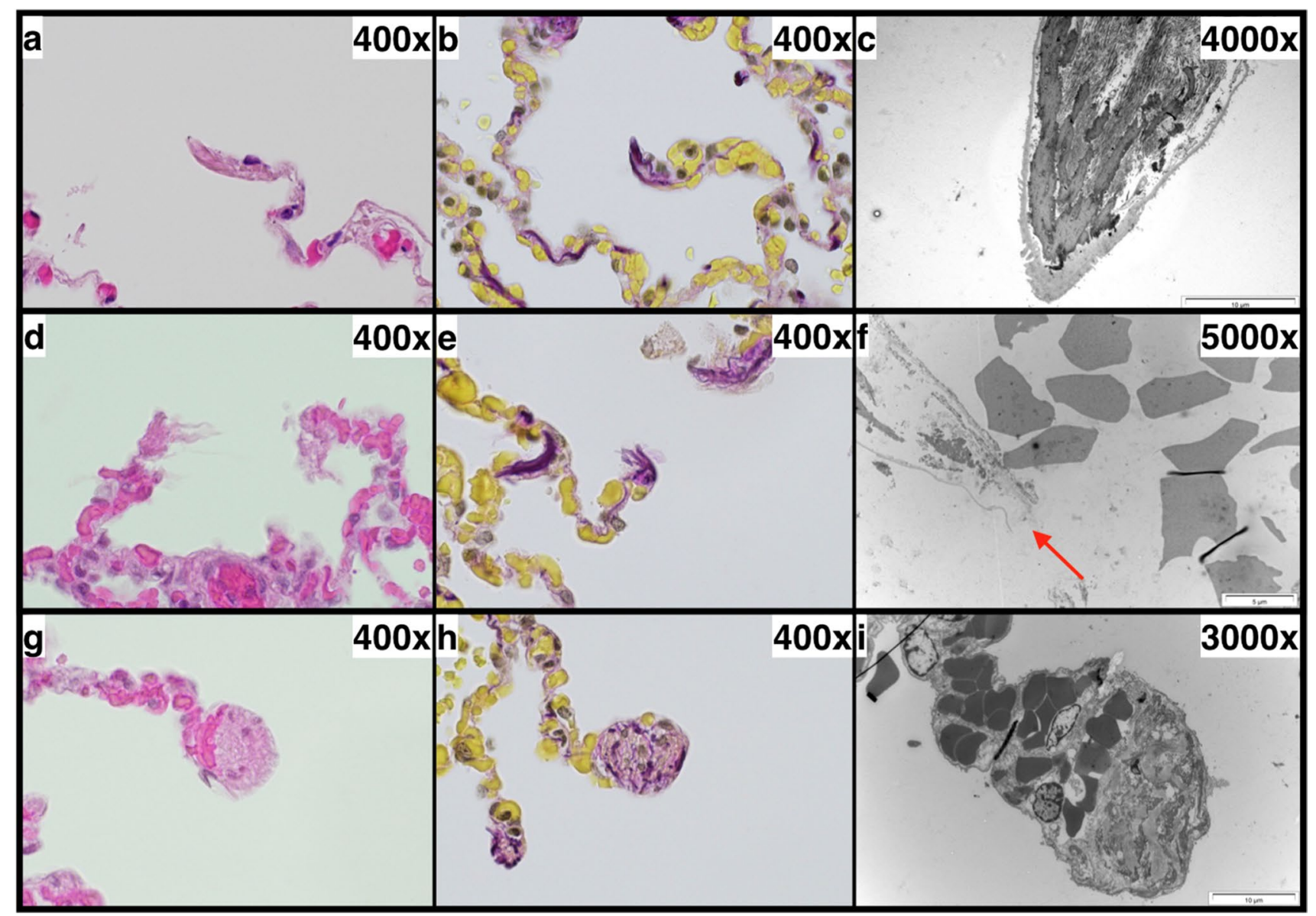

Fig. 2 Examples for the observed types of dead-ends: "smooth" dead-ends (a-c), "fringed" dead-ends (d-f), and "drumstick-like" dead-ends $(\mathbf{g}-\mathbf{i})(\mathbf{a}, \mathbf{d}, \mathbf{g}=$ hematoxylin-eosin stain; $\mathbf{b}, \mathbf{e}, \mathbf{h}=$ Elas-
tica-van-Gieson stain; c, $\mathbf{f}, \mathbf{i}=$ transmission electron microscopy; $*=$ erythrocytes; arrow $=$ membrane defect. $\mathbf{b}, \mathbf{d}, \mathbf{e}, \mathbf{g}-\mathbf{i}=$ cases with acute emphysema; $\mathbf{a}, \mathbf{c}, \mathbf{f}=$ cases with chronic emphysema)
"Drumstick-like" dead-ends were significantly more present in the "AE + CE" group than in the "NE" group $(p=0.006$, Fig. 3a). This type of dead-end was also observed frequently in the "CE" group (Fig. 3a); however, the difference between the "CE" group and the other groups was not significant.

"Fringed" dead-ends were significantly more frequently seen in the "AE" group than in the "CE" group $(p<0.001$, Fig. $3 b)$. They were also observed more frequently in the " $\mathrm{AC}+\mathrm{CE}$ " group than in the "CE" cases; however, this difference was not significant.

There were no significant differences in the "smooth" dead-ends among the groups (Fig. 3c).

Alveolar macrophages were significantly less frequently observed in the "CE" group and in the "AE + CE" group than in the "NE" group $(p<0.001$, Fig. $3 d)$.

\section{TEM}

The formalin-fixed material exhibited a sufficiently good image quality compared to the fresh lung tissue fixed directly during autopsy in conventional fixatives for electron microscopy. Thus, it was possible to examine tissue that was preserved up to 2 years ago.

All three types of dead-ends could be detected (Fig. 2), in "AE" as well as in "CE" cases. The morphological variability of all types of dead-ends was very high. For example, at the tip of some "drumstick-like" dead-ends, a thick, homogeneous submembranous layer could be observed (Fig. 4), especially in cases of CE. In the "AE" cases, we did not found this layer in any of three cases with detectable "drumstick-like" dead-ends, whereas in the "CE" cases, we found it in two out of four cases analyzed by TEM. 

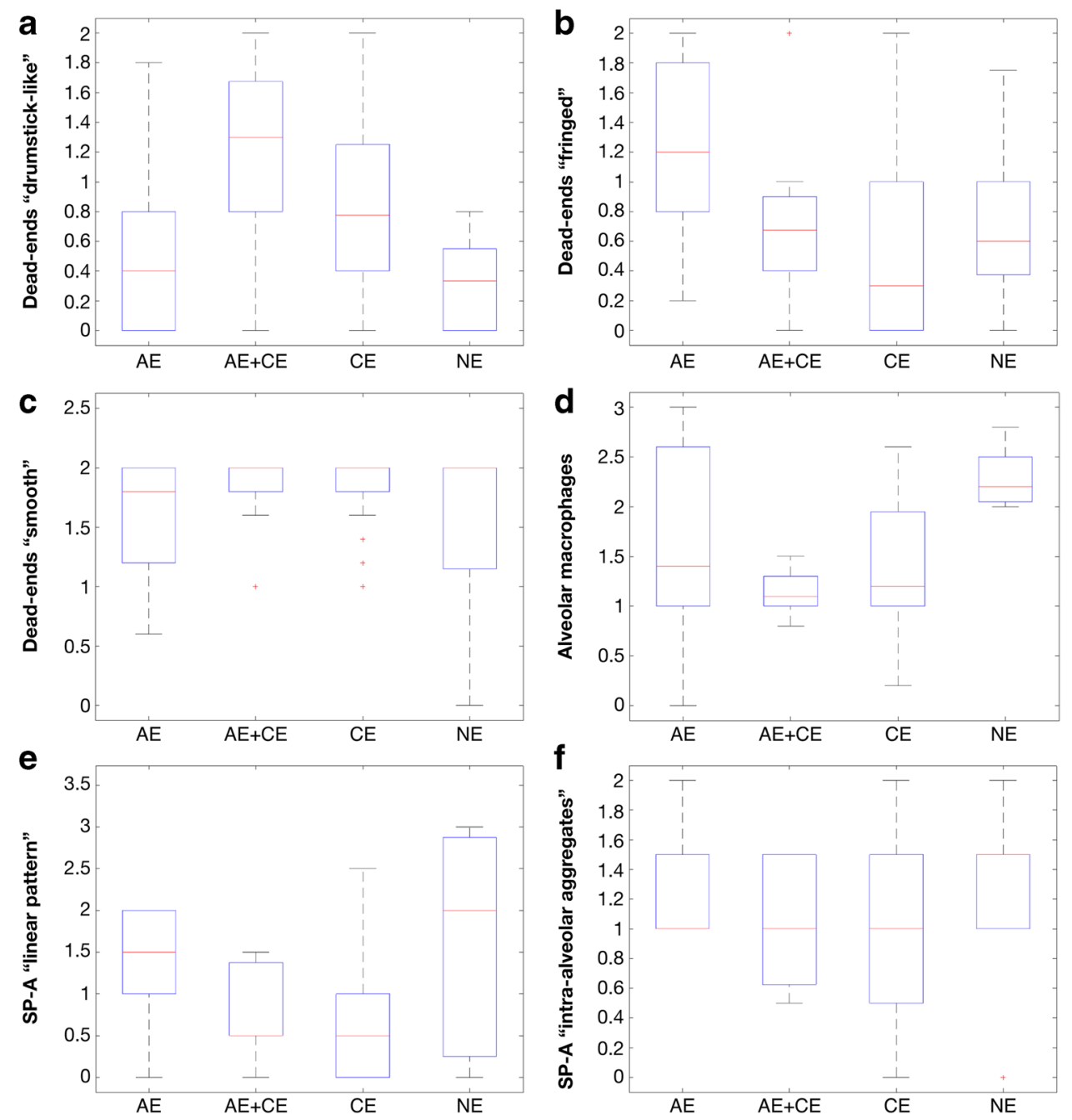

Fig. 3 1-way ANOVA analysis. The data sum up the findings from all pulmonary lobes. Boxplots show median and inter-quartile ranges. $p$-values $<0.05$, corrected for multiple comparisons using the false discovery rate (FDR), were considered significant. a Mean occurrence of "drumstick-like" dead-ends (from "0" = "none" to "2" = "many"). Significant difference between the "AE+CE" and the "NE" group $(p=0.006)$. b Mean occurrence of "fringed" deadends (from "0" ="none" to "2"= "many"). Significant difference between the "AE" and the "CE" group $(p<0.001)$. c Mean occurrence of "smooth" dead-ends (from "0"= "none" to " 2 " = "many").

d Mean occurrence of alveolar macrophages (from " 0 " = "none" to " 3 " = "many in clusters"). Significant differences between the "AE + CE" and the "NE" group $(p<0.001)$ and between "CE" and "NE" $(p<0.001)$. e Mean expression of the linear SP-A pattern (from " 0 " = "negative" to " 3 " = "strongly positive"). f Mean occurrence of intra-alveolar SP-A aggregates (from " 0 " = "negative" to " 3 " = "many massive aggregates in almost all alveoli") (AE=acute emphysema, $\mathrm{CE}=$ chronic emphysema, $\mathrm{AE}+\mathrm{CE}=$ acute + chronic emphysema, $\mathrm{NE}=$ no emphysema, $\mathrm{SP}-\mathrm{A}=$ surfactant protein $\mathrm{A}$ )

Fig. 4 Two examples for different "drumstick-like" dead-ends in transmission electron microscopy. a Acute emphysema (girl, age of 8 years). b Chronic emphysema (woman, age of 46 years). Thick, homogeneous submembrane layer at the tip of the dead-end (arrow)

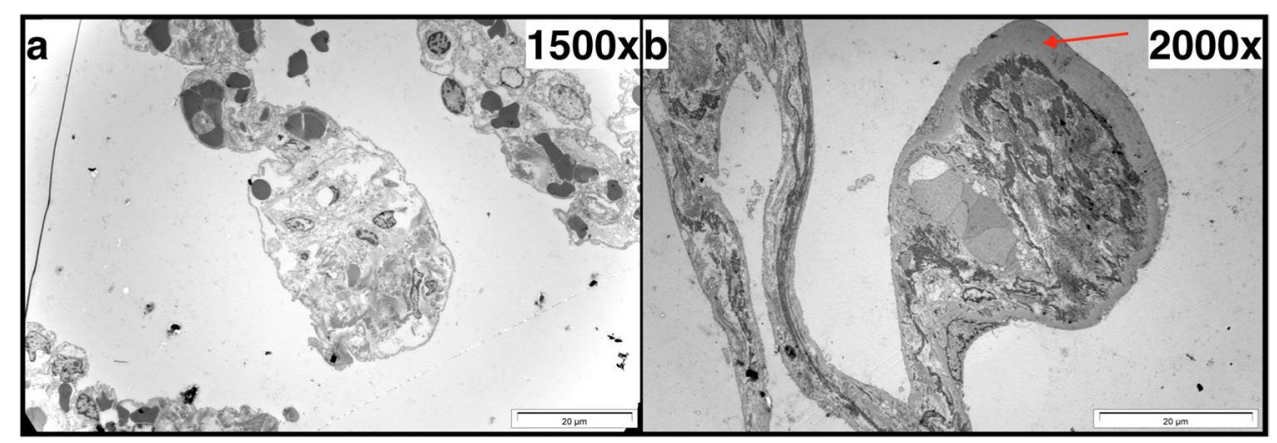




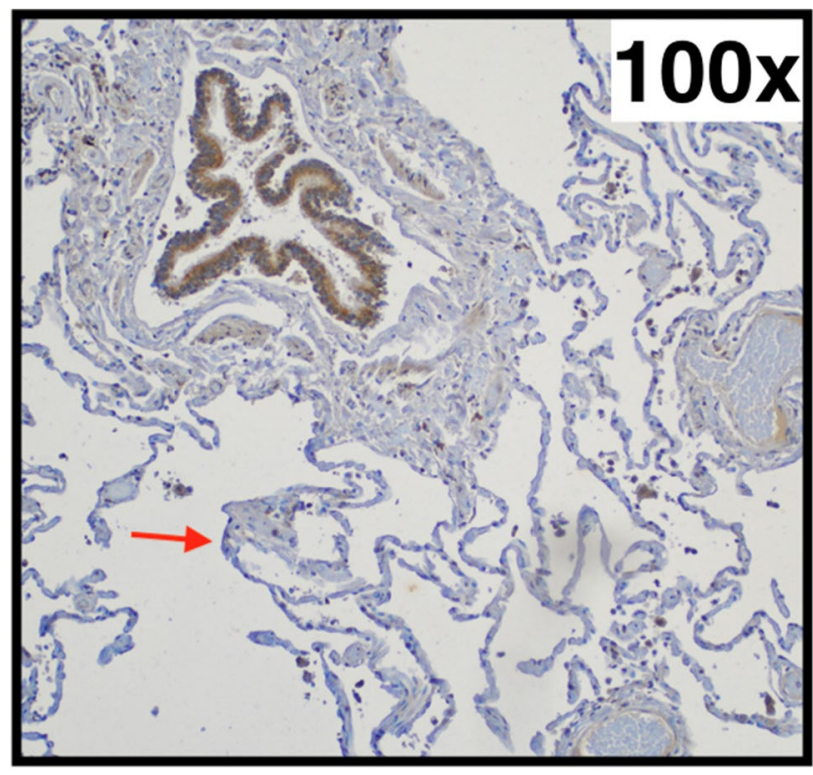

Fig. 5 Typical pulmonal findings in AQP-5 (aquaporin-5) immunohistochemistry (right lower lobe, 73-year-old woman with chronic emphysema): Strongly positive bronchial epithelium (upper left corner) next to negative pneumocytes type I (exemplary marked with an arrow)

\section{AQP-5 IHC}

In all investigated cases, the bronchial epithelium exhibited a strong expression of AQP-5 (internal positive control). However, the pneumocytes type I did not show a clear stainability in any case in all investigated groups (Fig. 5). The external positive and negative controls showed clear or missing stainability with AQP-5, respectively.

\section{SP-A IHC}

In principle, the SP-A patterns described in the literature could be reproduced in our samples (Figs. 6, 7). However, the marker did not show significantly different types of expression (linear pattern, intra-alveolar aggregates) between the groups (Fig. 3e, f). Even a separate examination of the right upper and lower lobe did not reveal any significant differences. The external positive and negative controls showed clear or missing stainability with SP-A, respectively; the internal control (smooth vascular muscle) was clearly positive in each case.

\section{Discussion}

\section{No specific pulmonary findings that would allow the diagnosis of "violent asphyxia" in cases with pre-existing CE}

Despite the extensive examination of numerous findings that are supposed to be typical for violent asphyxia, we could not identify any specific finding that would allow a reliable diagnosis in cases with acute and pre-existing chronic emphysema ("AE+CE").

The significantly more frequent occurrence of alveolar macrophages in the "NE" group compared to the "CE" and "AE + CE" groups contradicts our expectations. When interpreting the data, the numerous factors that influence the number of macrophages, like COPD [67, 68], must be considered. The agony time achieved in reality does not seem to provide a significantly increased number in cases of asphyxia, as already described by other authors like Gutjahr et al. [27].

With the exception of alveolar macrophages and deadends (see below), we consciously decided against a statistical evaluation of each light microscopic parameter in the 1-way ANOVA analysis separately. The reasons for this are firstly, that our current focus was the possible diagnosis of acute emphysema in cases with pre-existing chronic emphysema (which was an exclusion criteria in previous studies), so it is a pilot study with a low case number (statistical inconclusive), and secondly, that it is already known from the literature that the findings are not specific but only typical for violent asphyxiation.

Interstitial emphysema is described $[6,36]$ as a possible finding, in the older literature as a finding arising with prolonged asphyxia [69]. In our cases, we could not detect this, which is not in conflict with the literature, as it is not described as a constantly occurring parameter.
Fig. 6 Typical pulmonal findings in SP-A (surfactant protein A) immunohistochemistry. a Strong linear pattern $(+++)$ in a lung without emphysema of a 30-year-old man. b Strong intra-alveolar SP-A aggregates $(+++)$ in a lung without emphysema of a 27 -year-old man

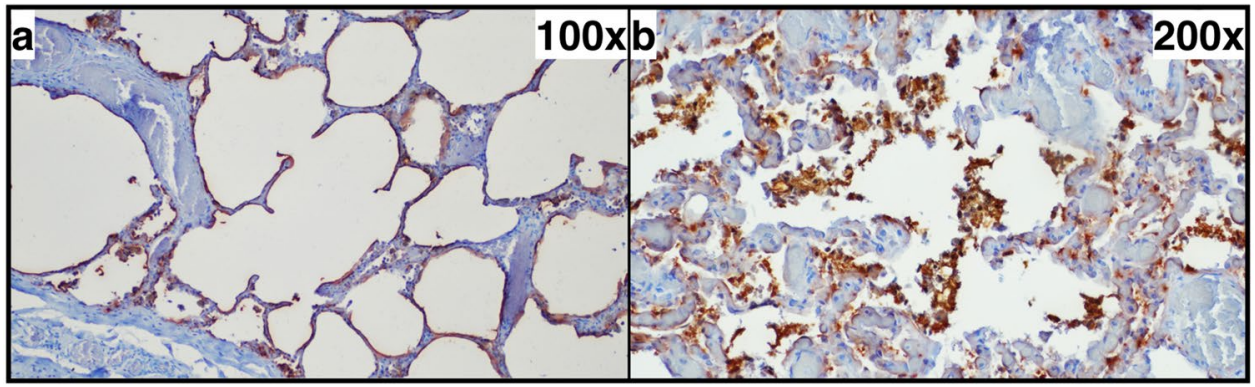


Fig. 7 SP-A immunohistochemistry. Both a linear pattern (a) and intra-alveolar aggregates (b) in the identical case but in different regions. Left upper lobe of a non-emphysematic lung from a 30-year-old man

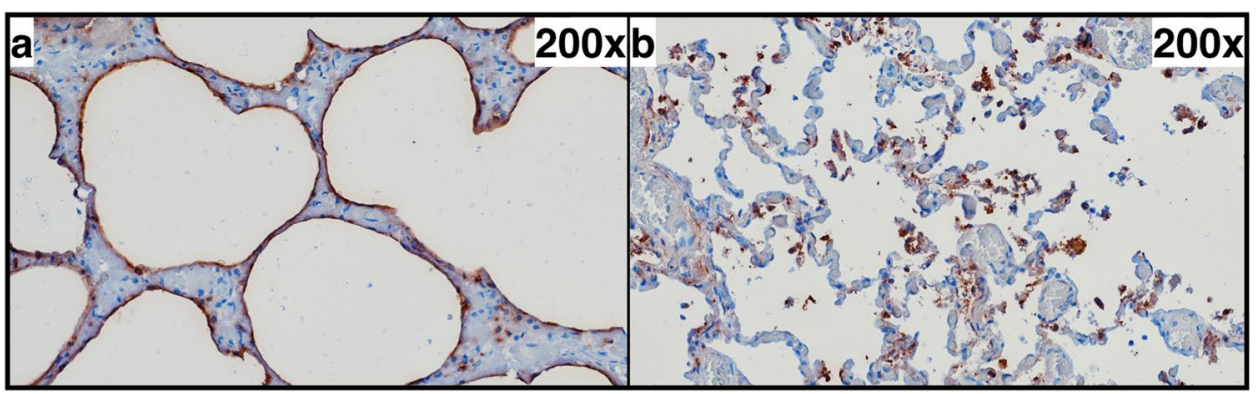

\section{The approach of a multivariate analysis of findings was not successful for the "AE + CE" group in this study but may nevertheless be interesting for future research}

The major advantage of the leave-one-out cross validation we used is that model performance can be evaluated with respect to their out-of-sample performance, i.e., we could estimate how well the model is able to correctly classify new cases.

Eighty-six percent of all "AE" and "CE" cases were correctly classified as "AE" and "CE" cases, respectively. Accordingly, the probability of incorrect classification of "AE" and "CE" cases was low (0-14\%). The multivariate model correctly classified only $50 \%$ of the "AE + CE" cases. The incorrect classified cases "AE + CE" cases were classified as "CE" cases. The unsatisfactory performance of the model in the "AC $+\mathrm{CE}$ " group may be caused by the low number of cases in the groups and the variability within a group due to the assignment to a group that was only done based on the type of emphysema, not based on the cause of death.

In any case, our findings suggest that multivariate approaches should be investigated further, albeit with a significantly larger number of cases, precisely defined groups, and taking into account other (immunohistochemical and molecular) parameters with diagnostic relevance. Interesting parameters could be further immunohistochemical markers as the hypoxia-inducible factor 1-alpha (HIF1- $\alpha$ [50]) or altered expression patterns of microRNAs from specific proteins in other organs like the myocardium or brain [70,71]. Furthermore, markers secreted by alveolar macrophages in a hypoxic environment might be of interest, such as MCP-1 [72-74].

\section{“Dead-ends" as diagnostic tools?}

The "smooth" dead-ends are most likely correlates of the alveolar septums' physiological shape since they were found in every specimen.

The "drumstick-like" dead-ends are to be interpreted as typical findings in chronic pulmonary emphysema. Their shape has already been described in the literature, for example, as "tennis racquet" or "clubbed"-appearing ends [75] or as "stump-like" alveolar septum ends [76]. Rapello et al. described "formations of drumsticks" in their study about pulmonary emphysema development in rat lungs after 90 days of exposure to methylphenidate [77]. However, it should be noted that these were also found in three childish and youthful lungs (7-, 8-, and 15-year-old individuals) of our cases, respectively, who had no evidence for chronic emphysema, so we do not consider them to be specific. We suggest that they may be the morphological correlate to a thickened ring structure ("basal ring" [78]) at the entrance of the alveoli. The occurrence of the homogeneous subepithelial layer at the tip of the "drumstick-like" dead-ends in adult "CE" cases (Fig. 4) may be a sign of a chronic remodelling process. Clarification of its significance requires further investigations.

The "fringed" dead-ends may be a correlate to alveolar wall ruptures and, therefore, a typical finding in acute emphysema. They are not specific since they were detected also in other forms of emphysema. It seems plausible that they may occur in diverse situations of tissue stress, e.g., during coughing attacks $[79,80]$. An advanced morphological categorization or a quantitative evaluation may increase the diagnostic value of "fringed" dead-ends.

\section{The immunohistochemical markers AQP-5 and SP-A did not reveal results of diagnostic value}

AQP-5, a transmembrane protein responsible for water transport and expressed mainly on pneumocytes type I [81-86], has been shown a reduced linear expression pattern in forms of asphyxiation in which the airways were obstructed [49] and in mice lungs after freshwater drowning [87]. However, other studies show no differences between fresh and salt water drowning [51] and that there is an increased expression in rat lungs after drowning [88].

We could not reproduce this staining pattern in any case. We have no explanation for the pneumocyte type I lacking stainability with our used marker for AQP-5, since both the internal and the external positive control were clearly stained. One possible explanation could be that our primary 
antibodies bind to different epitopes than those used in other studies, such as those by Wang et al. [49] or Hayashi et al. [87].

SP-A is an essential component of the surfactant; it is expressed by pneumocytes type II and Clara cells (meanwhile known as club cells) and reduces the surface tension of the alveoli [89-91]. It has been shown to be significantly more expressed in human and animal lungs after (mechanical) asphyxia and drowning (especially a distinct "granular pattern" is described) [42-48, 50, 51, 62].

In our hands, the immunohistochemical SP-A pattern showed up as we expected from the previous literature. We noticed that the intensity of the same specimen's findings could vary widely, which is why we only evaluated the areas with the most pronounced findings. We saw in the same specimen that a clear linear pattern could be seen next to distinct intra-alveolar aggregates (Fig. 7). However, it did not occur that both patterns appear at the same spot within one specimen, so it seems plausible that the intra-alveolar aggregates are a "sheared off" linear pattern. The lack of significant differences between the groups may be explained by the high variability of the individual cases within the groups and the small case number.

For both IHC markers, it must be noted that their expression is also dependent on other circumstances. For AQP-5, it could already be shown in animal experiments that the expression decreases in case of an adenovirus infection [92] or lung fibrosis [93]. Besides, the bronchial epithelium assessment may be complicated because, in some cases, it has detached from the bronchial wall, for example, due to suction effects or autolysis [35]. The SP-A pattern is highly influenced by pulmonary edema [94], which can also emerge after death [95]. Less SP-A is supposed to be expressed in COPD patients [96] and CO intoxication [65]. Increased SP-A stainability has been shown, for example, in perinatal aspiration of amniotic fluid, fire victims, and intoxications, e.g., with methamphetamine, organophosphates, or muscle relaxants $[43,47$, 65]. Due to the lack of specificity, positive findings must be critically evaluated.

\section{Limitations of this study}

We categorized our cases primarily according to the form of emphysema and did not further subdivide the groups according to the forms of asphyxia since we wanted to address the situation "Suspected asphyxiation/suffocation, discrete external findings, unclear course of events"; the resulting high variability of cases (Table 3) should increase the informative value of this pilot study. However, this variability made the interpretation of our findings partly tricky. The individual cases assignment to the groups was made after considering all available
Table 3 Causes of death within the four diagnosis groups ( $A E$ acute emphysema, $C E$ chronic emphysema, $A E+C E$ acute +chronic emphysema, $N E$ no emphysema)

\begin{tabular}{|c|c|c|}
\hline Group & Cause of death & $n$ \\
\hline \multirow[t]{8}{*}{$\mathrm{AE}$} & Atypical hanging & 9 \\
\hline & Burking & 1 \\
\hline & Drowning & 4 \\
\hline & Fatal aspiration & 1 \\
\hline & Oronasal occlusion & 1 \\
\hline & Resuscitation & 2 \\
\hline & Status asthmaticus & 1 \\
\hline & Strangulation & 3 \\
\hline \multirow[t]{5}{*}{$\mathrm{AE}+\mathrm{CE}$} & Aspiration & 1 \\
\hline & Atypical hanging & 3 \\
\hline & Drowning & 2 \\
\hline & Oronasal occlusion & 1 \\
\hline & Strangulation & 5 \\
\hline \multirow[t]{10}{*}{$\mathrm{CE}$} & Bleeding & 4 \\
\hline & Cardial death & 21 \\
\hline & $\mathrm{CO}$ intoxication & 1 \\
\hline & Craniocerebral injury & 2 \\
\hline & Gunshot & 1 \\
\hline & Hypothermia & 2 \\
\hline & Intoxication & 1 \\
\hline & Polytrauma & 5 \\
\hline & Sepsis & 5 \\
\hline & Viral infect & 1 \\
\hline \multirow[t]{5}{*}{ NE } & Decapitation & 1 \\
\hline & Heart failure & 1 \\
\hline & Intoxication & 1 \\
\hline & Polytrauma & 2 \\
\hline & Sepsis & 2 \\
\hline
\end{tabular}

information and to the best of our knowledge. Therefore, the form of emphysema of an individual was therefore always only the expected form of emphysema because the actual form could not be proven with absolute certainty. Further investigations should differentiate between the various forms of asphyxia, considering the partly different definitions in the literature [97], and use a larger number of cases.

\section{Conclusion}

In summary, we could not identify any specific morphologic finding or pattern that would allow a reliable diagnosis of acute emphysema or death by violent asphyxia, respectively, if chronic emphysema is pre-existing. However, we identified "fringed dead-ends" as an interesting and typical (but not specific) finding in $\mathrm{AE}$ that deserves 
further investigation. Though the multivariate analysis of findings was not successful for the "AE + CE" group in this study, this approach may be interesting for future research. In light of the complexity of violent asphyxiation's pathophysiology, it seems unlikely to find specific diagnostic parameters. In the absence of specific findings, diagnoses must be based on at best many typical findings. Multivariate approaches may be an interesting tool to support the reliability of diagnoses based on typical but not specific findings. They should be investigated further, using large numbers of cases, precisely defined groups, and taking into account several morphological and molecular parameters with diagnostic relevance.

Acknowledgements We thank Nassra Boczkowski, Georga Flint, and Elisabeth Wesbuer for their technical support.

Author contribution Conceptualization: Ritz-Timme, Gava, Mahlke. Data curation: Gava, Mahlke

Formal analysis and investigation: Gava, Mahlke, Ritz-Timme, Eickhoff, Filler

Methodology: Gava, Mahlke, Mayer, Ritz-Timme, Eickhoff, Filler

Project administration: Gava, Mahlke

Resources: Ritz-Timme, Eickhoff, Filler

Software: Eickhoff

Supervision: Ritz-Timme, Filler, Mahlke

Validation: Gava, Mahlke, Ritz-Timme, Eickhoff

Visualization: Gava, Mahlke, Ritz-Timme, Eickhoff

Writing - original draft: Gava

Writing - review and editing: Ritz-Timme, Mahlke, Eickhoff, Mayer, Filler

Funding Open Access funding enabled and organized by Projekt DEAL.

\section{Declarations}

Ethics approval All procedures performed in studies involving human tissue were in accordance with the ethical standards of the institutional and/or national research committee and with the 1964 Helsinki declaration and its later amendments or comparable ethical standards (approved by Ethics Committee at the Medical Faculty of HeinrichHeine University: 2018-154-KFogU). This article does not contain any studies with animals performed by any of the authors.

Conflict of interest The authors declare no competing interests.

Open Access This article is licensed under a Creative Commons Attribution 4.0 International License, which permits use, sharing, adaptation, distribution and reproduction in any medium or format, as long as you give appropriate credit to the original author(s) and the source, provide a link to the Creative Commons licence, and indicate if changes were made. The images or other third party material in this article are included in the article's Creative Commons licence, unless indicated otherwise in a credit line to the material. If material is not included in the article's Creative Commons licence and your intended use is not permitted by statutory regulation or exceeds the permitted use, you will need to obtain permission directly from the copyright holder. To view a copy of this licence, visit http://creativecommons.org/licenses/by/4.0/.

\section{References}

1. Nasemann J (1982) Tierexperimentelle Untersuchungen zur Frage des akuten Emphysems bei Strangulation. Beitr Gerichtl Med 40:123-128

2. Koops E, Kleiber M, Brinkmann B (1982) Über Befundmuster und besondere Befunde bei homicidalem und suicidalem Erdrosseln. Beitr Gerichtl Med 40:129-133

3. Klysner A, Lynnerup N, Hougen HP (2011) Is acute alveolar dilation an indicator of strangulation homicide? Med Sci Law 51(2):102-105. https://doi.org/10.1258/msl.2011.010132

4. Geserick G, Kämpfe U (1990) Zur Bedeutung von Stauungsblutungen bei der gewaltsamen Asphyxie. In: Brinkmann B, Püschel K (eds) Ersticken. Springer, Berlin Heidelberg, Berlin, pp 73-85. https://doi.org/10.1007/978-3-642-75757-0_11

5. Dettmeyer R, Veit F, Verhoff MA (2019) Gewalt gegen den Hals. In: Dettmeyer R, Veit F, Verhoff MA (eds) Rechtsmedizin, 3 edn. Springer, Berlin Heidelberg, pp 95-103. https://doi.org/10.1007/ 978-3-662-58658-7

6. Brinkmann B (2004) Ersticken. In: Brinkmann B, Madea B (eds) Handbuch gerichtliche Medizin, vol 1. Springer, Berlin Heidelberg, pp 699-796

7. Keil W, Lunetta P, Vann R, Madea B (2014) Injuries due to Asphyxiation and Drowning. In: Madea B (ed) Handbook of forensic medicine. Wiley Blackwell, pp 367-450

8. Haarhoff K (1971) Autoptische Befunde beim Erwürgen und Erdrosseln. Beitr Gerichtl Med 28:137-142

9. Reay DT, Eisele JW (1982) Death from law enforcement neck holds. Am J Forensic Med Pathol 3(3):253-258. https://doi.org/ 10.1097/00000433-198209000-00012

10. Maxeiner H, Schneider V (1985) Zum Erstickungstode beim Verschluß der Atemöffnungen durch Sand. Z Rechtsmed 94(3):173-189

11. Banaschak S, Schmidt P, Madea B (2003) Smothering of children older than 1 year of age-diagnostic significance of morphological findings. Forensic Sci Int 134(2-3):163-168. https:// doi.org/10.1016/s0379-0738(03)00135-x

12. Buschmann CT, Rosenbaum F, Tsokos M (2008) Ein Fall von überlebter Thoraxkompression durch Beknien-"Burking." Arch Kriminol 222(128):e32

13. Prasad DD (2014) Burking: a case report. J Evol Med Dent Sci 3(39):9959-9964

14. Berzlanovich AM, Schöpfer J, Keil W (2012) Deaths due to physical restraint. Dtsch Arztebl Int 109(3):27-32. https://doi. org/10.3238/arztebl.2012.0027

15. Janssen W (1969) Der forensische Beweiswert histologischer Untersuchungen. Beitr Gerichtl Med 25:51-60

16. Reh H (1979) Vitale Reaktionen der Atmungsorgane. Beitr Gerichtl Med 37:121-126

17. Brinkmann B, Fechner G, Puschel K (1984) Identification of mechanical asphyxiation in cases of attempted masking of the homicide. Forensic Sci Int 26(4):235-245. https://doi.org/10. 1016/0379-0738(84)90028-8

18. Sadler DW (1994) Concealed homicidal strangulation first discovered at necropsy. J Clin Pathol 47(7):679-680. https://doi. org/10.1136/jcp.47.7.679

19. Schmeling A, Fracasso T, Pragst F, Tsokos M, Wirth I (2009) Unassisted smothering in a pillow. Int J Legal Med 123(6):517519. https://doi.org/10.1007/s00414-009-0362-7

20. Brinkmann B (1978) Vital reactions of the pulmonary circulation in fatal strangulation (author's transl). Zeitschrift fur Rechtsmedizin Journal of legal medicine 81(2):133-146

21 Brinkmann B, Puschel K (1981) Histomorphological alterations of lung after strangulation. A comparative experimental study 
(author's trans1). Zeitschrift fur Rechtsmedizin J Legal Med 86(3):175-194. https://doi.org/10.1007/BF00203794

22. Grellner W, Madea B (2021) Histopathology of the lung in asphyxiation, suffocation and pressure to the neck. In: Madea B (ed) Asphyxiation, suffocation, and neck pressure deaths. CRC Press Taylor \& Francis Group, Boca Raton, pp 120-123

23. Keil W, Berzlanovich A (2010) Ersticken durch weiche Bedeckung. Rechtsmedizin 20(6):519-528. https://doi.org/10.1007/ s00194-010-0714-0

24. Pollak S (1975) Über die Häufigkeit des Lungenödems beim Erhängungstod. Beitr Gerichtl Med 33:134-138

25. Wiese J, Maxeiner H, Schneider V (1990) Histologische Lungenbefunde beim Würgen und Drosseln. In: Brinkmann B, Püschel K (eds) Ersticken. Springer, Berlin Heidelberg, Berlin, pp 158-171. https://doi.org/10.1007/978-3-642-75757-0_20

26. Grellner W, Madea B (1994) Pulmonary micromorphology in fatal strangulations. Forensic Sci Int 67(2):109-125. https://doi. org/10.1016/0379-0738(94)90326-3

27. Gutjahr E, Madea B (2019) Inflammatory reaction patterns of the lung as a response to alveolar hypoxia and their significance for the diagnosis of asphyxiation. Forensic Sci Int 297:315-325. https://doi.org/10.1016/j.forsciint.2019.02.026

28. Brinkmann B (1978) Zur Pathophysiologie und Pathomorphologie bei Tod durch Druckstauung. Z Rechtsmed 81(2):79-96

29. Du Chesne A, Cecchi-Mureani R, Puschel K, Brinkmann B (1996) Macrophage subtype patterns in protracted asphyxiation. Int $\mathrm{J}$ Legal Med 109(4):163-166. https://doi.org/10.1007/BF01225512

30. Vacchiano G, D'Armiento F, Torino R (2001) Is the appearance of macrophages in pulmonary tissue related to time of asphyxia? Forensic Sci Int 115(1-2):9-14. https://doi.org/10.1016/s03790738(00)00301-7

31. Strunk T, Hamacher D, Schulz R, Brinkmann B (2010) Reaction patterns of pulmonary macrophages in protracted asphyxiation. Int J Legal Med 124(6):559-568. https://doi.org/10.1007/ s00414-009-0410-3

32. Betz P, Nerlich A, Penning R, Eisenmenger W (1993) Pulmonary giant cells and their significance for the diagnosis of asphyxiation. Int J Legal Med 106(3):156-159. https://doi.org/10.1007/BF012 25239

33. Betz P, Beier G, Eisenmenger W (1994) Pulmonary giant cells and traumatic asphyxia. Int J Legal Med 106(5):258-261. https:// doi.org/10.1007/BF01225416

34. Grellner W, Madea B (1996) Immunohistochemical characterization of alveolar macrophages and pulmonary giant cells in fatal asphyxia. Forensic Sci Int 79(3):205-213. https://doi.org/10.1016/ 0379-0738(96)01913-5

35. Gutjahr E, Madea B (2020) Diagnose einer gewaltsamen Erstickung: Teil 1: Reevaluation der Spezifität makroskopischer und histomorphologischer Befunde. Rechtsmedizin 30(1):55-63

36. Püschel K, Lach H (2004) Gewaltsames Ersticken. In: Madea B, Bratzke H, Pollak S, Püschel K, Rothschild M (eds) 100 Jahre Deutsche Gesellschaft für Gerichtliche Medizin/Rechtsmedizin: vom Gründungsbeschluss 1904 zur Rechtsmedizin des 21. Jahrhunderts. Deutsche Gesellschaft für Rechtsmedizin, Essen, pp 800-815

37. Witschel H, Schulz E (1970) Lungenveränderungen bei künstlicher Beatmung. Z Rechtsmed 67(6):329-341

38. Houston JC, De Navasquez S, Trounce JR (1953) A clinical and pathological study of fatal cases of status asthmaticus. Thorax 8(3):207-213. https://doi.org/10.1136/thx.8.3.207

39. Heinen M, Dotzauer G (1973) Problemfall:"Ertrinkungslunge." Beitr Gerichtl Med 30:133

40. Giorgetti R, Bellero R, Giacomelli L, Tagliabracci A (2009) Morphometric investigation of death by asphyxia. J Forensic Sci 54(3):672-675. https://doi.org/10.1111/j.1556-4029.2009.01023.x
41. Kohlhase C, Maxeiner H (2003) Morphometric investigation of emphysema aquosum in the elderly. Forensic Sci Int 134(2-3):9398. https://doi.org/10.1016/s0379-0738(03)00136-1

42. Zhu BL, Maeda H, Fukita K, Sakurai M, Kobayashi Y (1996) Immunohistochemical investigation of pulmonary surfactant in perinatal fatalities. Forensic Sci Int 83(3):219-227. https://doi. org/10.1016/s0379-0738(96)02040-3

43. Zhu BL, Ishida K, Quan L, Fujita MQ, Maeda H (2000) Immunohistochemistry of pulmonary surfactant apoprotein A in forensic autopsy: reassessment in relation to the causes of death. Forensic Sci Int 113(1-3):193-197. https://doi.org/10.1016/s03790738(00)00264-4

44. Zhu BL, Ishida K, Fujita MQ, Maeda H (2000) Immunohistochemical investigation of a pulmonary surfactant in fatal mechanical asphyxia. Int J Legal Med 113(5):268-271. https://doi.org/10. 1007/s004149900109

45. Zhu BL, Ishida K, Quan L, Li DR, Taniguchi M, Fujita MQ, Maeda H, Tsuji T (2002) Pulmonary immunohistochemistry and serum levels of a surfactant-associated protein A in fatal drowning. Leg Med (Tokyo) 4(1):1-6. https://doi.org/10.1016/s13446223(01)00051-7

46. Ishida K, Zhu BL, Maeda H (2002) A quantitative RT-PCR assay of surfactant-associated protein A1 and A2 mRNA transcripts as a diagnostic tool for acute asphyxial death. Leg Med (Tokyo) 4(1):7-12. https://doi.org/10.1016/s1344-6223(01)00056-6

47. Maeda H, Fujita MQ, Zhu B-L, Ishida K, Quan L, Oritani S, Taniguchi M (2003) Pulmonary surfactant-associated protein A as a marker of respiratory distress in forensic pathology: assessment of the immunohistochemical and biochemical findings. Leg Med 5:S318-S321. https://doi.org/10.1016/s1344-6223(02)00160-8

48. Perez-Carceles MD, Sibon A, Vizcaya MA, Osuna E, GomezZapata M, Luna A, Martinez-Diaz F (2008) Histological findings and immunohistochemical surfactant protein A (SP-A) expression in asphyxia: its application in the diagnosis of drowning. Histol Histopathol 23(9):1061-1068. https://doi.org/10.14670/HH-23. 1061

49. Wang Q, Ishikawa T, Michiue T, Zhu BL, Guan DW, Maeda H (2012) Intrapulmonary aquaporin-5 expression as a possible biomarker for discriminating smothering and choking from sudden cardiac death: a pilot study. Forensic Sci Int 220(1-3):154-157. https://doi.org/10.1016/j.forsciint.2012.02.013

50. Cecchi R, Sestili C, Prosperini G, Cecchetto G, Vicini E, Viel G, Muciaccia B (2014) Markers of mechanical asphyxia: immunohistochemical study on autoptic lung tissues. Int J Legal Med 128(1):117-125. https://doi.org/10.1007/s00414-013-0876-x

51. Barranco R, Castiglioni C, Ventura F, Fracasso T (2019) Immunohistochemical expression of P-selectin, SP-A, HSP70, aquaporin 5 , and fibronectin in saltwater drowning and freshwater drowning. Int J Legal Med 133(5):1461-1467. https://doi.org/10.1007/ s00414-019-02105-1

52. Brinkmann B, Püschel K, Bause H-W, Doehn M (1981) Zur Pathophysiologie der Atmung und des Kreislaufs bei Tod durch obstruktive Asphyxie. Zeitschrift fuer Rechtsmedizin 87-87(12):103-116. https://doi.org/10.1007/bf00201215

53 Verbeken EK, Cauberghs M, Mertens I, Clement J, Lauweryns JM, Van de Woestijne KP (1992) The senile lung. Comparison with normal and emphysematous lungs. 1. Structural aspects. Chest 101(3):793-799. https://doi.org/10.1378/chest.101.3.793

54. Janssens JP, Pache JC, Nicod LP (1999) Physiological changes in respiratory function associated with ageing. Eur Respir J 13(1):197-205. https://doi.org/10.1034/j.1399-3003.1999.13a36.x

55. Fukuchi Y (2009) The aging lung and chronic obstructive pulmonary disease: similarity and difference. Proc Am Thorac Soc 6(7):570-572. https://doi.org/10.1513/pats.200909-099RM 
56. Brashier BB, Kodgule R (2012) Risk factors and pathophysiology of chronic obstructive pulmonary disease (COPD). J Assoc Physicians India 60 Suppl(Suppl):17-21

57. Fregonese L, Stolk J (2008) Hereditary alpha-1-antitrypsin deficiency and its clinical consequences. Orphanet J Rare Dis 3(1):16. https://doi.org/10.1186/1750-1172-3-16

58. Hartung W (1966) Zur pathologischen Anatomie des Lungenemphysems. Beitr Klin Erforsch Tuberk Lungenkr 133(3):225-236

59. Finlay GA, O’Donnell MD, O'Connor CM, Hayes JP, FitzGerald MX (1996) Elastin and collagen remodeling in emphysema. A scanning electron microscopy study. Am J Pathol 149(4):1405-1415

60. Vlahovic G, Russell ML, Mercer RR, Crapo JD (1999) Cellular and connective tissue changes in alveolar septal walls in emphysema. Am J Respir Crit Care Med 160(6):2086-2092. https://doi. org/10.1164/ajrccm.160.6.9706031

61. O'Donnell MD, O'Connor CM, FitzGerald MX, Lungarella G, Cavarra E, Martorana PA (1999) Ultrastructure of lung elastin and collagen in mouse models of spontaneous emphysema. Matrix Biol 18(4):357-360. https://doi.org/10.1016/s0945-053x(99) 00031-1

62. Lee SY, Woo SK, Lee SM, Ha EJ, Lim KH, Choi KH, Roh YH, Eom YB (2017) Microbiota composition and pulmonary surfactant protein expression as markers of death by drowning. J Forensic Sci 62(4):1080-1088. https://doi.org/10.1111/15564029.13347

63. Mulisch M, Welsch U (2010) Färbungen. Romeis Mikroskopische Technik, 18th edn. Spektrum Akademischer Verlag, Heidelberg, pp 181-297

64. Kellner U (2019) Adaptive/regressive Erkrankungen des Herzens. In: Kellner U, Frahm S, Mawrin C, Krams M (eds) Kurzlehrbuch Pathologie, 3 edn. Thieme Stuttgart, pp 101-103. https://doi.org/10.1055/b-007-167433

65. Zhu BL, Ishida K, Oritani S, Quan L, Taniguchi M, Li DR, Fujita MQ, Maeda H (2001) Immunohistochemical investigation of pulmonary surfactant-associated protein A in fire victims. Leg Med (Tokyo) 3(1):23-28. https://doi.org/10.1016/s13446223(01)00006-2

66. Reynolds ES (1963) The use of lead citrate at high $\mathrm{pH}$ as an electron-opaque stain in electron microscopy. J Cell Biol 17(1):208-212. https://doi.org/10.1083/jcb.17.1.208

67. Barnes PJ (2004) Alveolar macrophages as orchestrators of COPD. COPD 1(1):59-70

68. Hogg JC, Chu F, Utokaparch S, Woods R, Elliott WM, Buzatu L, Cherniack RM, Rogers RM, Sciurba FC, Coxson HO, Pare PD (2004) The nature of small-airway obstruction in chronic obstructive pulmonary disease. N Engl J Med 350(26):26452653. https://doi.org/10.1056/NEJMoa032158

69. Ponsold A, Berg S (1967) Die Erstickung im Allgemeinen. In: Ponsold A (ed) Lehrbuch der gerichtlichen Medizin. Georg Thieme, Stuttgart, pp 313-319

70. Zeng Y, Lv Y, Tao L, Ma J, Zhang H, Xu H, Xiao B, Shi Q, Ma $\mathrm{K}$, Chen L (2016) G6PC3, ALDOA and CS induction accompanies mir-122 down-regulation in the mechanical asphyxia and can serve as hypoxia biomarkers. Oncotarget 7(46):7452674536. https://doi.org/10.18632/oncotarget.12931

71. Han L, Zhang H, Zeng Y, Lv Y, Tao L, Ma J, Xu H, Ma K, Shi Q, Xiao B, Chen L (2020) Identification of the miRNA-3185/ CYP4A11 axis in cardiac tissue as a biomarker for mechanical asphyxia. Forensic Sci Int 311:110293. https://doi.org/10. 1016/j.forsciint.2020.110293

72. Chao J, Wood JG, Blanco VG, Gonzalez NC (2009) The systemic inflammation of alveolar hypoxia is initiated by alveolar macrophage-borne mediator(s). Am J Respir Cell Mol Biol 41(5):573-582. https://doi.org/10.1165/rcmb.2008-04170C
73. Chao J, Wood JG, Gonzalez NC (2009) Alveolar hypoxia, alveolar macrophages, and systemic inflammation. Respir Res 10(1):54. https://doi.org/10.1186/1465-9921-10-54

74. Chao J, Donham P, van Rooijen N, Wood JG, Gonzalez NC (2011) Monocyte chemoattractant protein-1 released from alveolar macrophages mediates the systemic inflammation of acute alveolar hypoxia. Am J Respir Cell Mol Biol 45(1):53-61. https://doi.org/10.1165/rcmb.2010-0264OC

75. Cummings PM, Trelka DP, Springer KM (2011) Sudden death. In: Atlas of forensic histopathology. Cambridge University Press, Cambridge, pp 92-152

76. Thomas C (2004) Lunge. Histopathologie kompakt: Kursbuch der allgemeinen und speziellen Histopathologie. Schattauer Verlag, Stuttgart, pp 16-33

77. Rapello GV, Antoniolli A, Pereira DM, Facco G, Pego-Fernandes PM, Pazetti R (2015) Pulmonary emphysema induced by methylphenidate: experimental study. Sao Paulo Med J 133(2):131-134. https://doi.org/10.1590/1516-3180.2014. 8470910

78. Schmitz F (2020) Atmungsorgane und Pleura. In: Aumueller G, Aust G, Conrad A et al. (eds) Duale Reihe Anatomie, 5 edn. Thieme Stuttgart, pp 541-577. https://doi.org/10. 1055/b-007-170976

79. Wang H, Nugent WC (2010) Cough-induced bilateral spontaneous pneumothorax. Ann Thorac Surg 90(4):1363-1365. https:// doi.org/10.1016/j.athoracsur.2010.04.024

80. Riede UN, Kayser G, Freudenberg N, Matthys H (2017) Lunge. In: Riede U-N, Werner M (eds) Allgemeine und spezielle Pathologie, 2 edn. Springer, Berlin Heidelberg, pp 411-434. https://doi.org/10.1007/978-3-662-48725-9

81. Borgnia M, Nielsen S, Engel A, Agre P (1999) Cellular and molecular biology of the aquaporin water channels. Annu Rev Biochem 68(1):425-458. https://doi.org/10.1146/annurev.bioch em.68.1.425

82. Verkman AS, Matthay MA, Song Y (2000) Aquaporin water channels and lung physiology. Am J Physiol Lung Cell Mol Physiol 278(5):L867-879. https://doi.org/10.1152/ajplung.2000. 278.5.L867

83. Verkman AS, Mitra AK (2000) Structure and function of aquaporin water channels. Am J Physiol Renal Physiol 278(1):F1328. https://doi.org/10.1152/ajprenal.2000.278.1.F13

84. Verkman AS (2002) Aquaporin water channels and endothelial cell function. J Anat 200(6):617-627. https://doi.org/10.1046/j. 1469-7580.2002.00058.x

85. King LS, Kozono D, Agre P (2004) From structure to disease: the evolving tale of aquaporin biology. Nat Rev Mol Cell Biol 5(9):687-698. https://doi.org/10.1038/nrm1469

86. Benga G (2009) Water channel proteins (later called aquaporins) and relatives: past, present, and future. IUBMB Life 61(2):112133. https://doi.org/10.1002/iub.156

87. Hayashi T, Ishida Y, Mizunuma S, Kimura A, Kondo T (2009) Differential diagnosis between freshwater drowning and saltwater drowning based on intrapulmonary aquaporin-5 expression. Int J Legal Med 123(1):7-13. https://doi.org/10.1007/ s00414-008-0235-5

88. Lee SY, Ha EJ, Cho HW, Kim HR, Lee D, Eom YB (2019) Potential forensic application of receptor for advanced glycation end products (RAGE) and aquaporin 5 (AQP5) as novel biomarkers for diagnosis of drowning. J Forensic Leg Med 62:56-62. https://doi.org/10.1016/j.jflm.2019.01.007

89. Phelps DS, Floros J (1988) Localization of surfactant protein synthesis in human lung by in situ hybridization. Am Rev Respir Dis 137(4):939-942. https://doi.org/10.1164/ajrccm/ 137.4.939 
90. Hawgood S, Clements JA (1990) Pulmonary surfactant and its apoproteins. J Clin Invest 86(1):1-6. https://doi.org/10.1172/ JCI1 14670

91. Heinrich S, Hartl D, Griese M (2006) Surfactant protein A-from genes to human lung diseases. Curr Med Chem 13(27):32393252. https://doi.org/10.2174/092986706778773112

92. Towne JE, Harrod KS, Krane CM, Menon AG (2000) Decreased expression of aquaporin (AQP) 1 and AQP5 in mouse lung after acute viral infection. Am J Respir Cell Mol Biol 22(1):34-44. https://doi.org/10.1165/ajrcmb.22.1.3818

93. Gabazza EC, Kasper M, Ohta K, Keane M, D’AlessandroGabazza C, Fujimoto H, Nishii Y, Nakahara H, Takagi T, Menon AG, Adachi Y, Suzuki K, Taguchi O (2004) Decreased expression of aquaporin-5 in bleomycin-induced lung fibrosis in the mouse. Pathol Int 54(10):774-780. https://doi.org/10.1111/j. 1440-1827.2004.01754.x

94. Campobasso CP, Colonna MF, Zotti F, Sblano S, Dell'Erba AS (2012) An immunohistochemical study of pulmonary surfactant apoprotein A (SP-A) in forensic autopsy materials. Rom J Leg Med 20(1):1-12. https://doi.org/10.4323/rjlm.2012.1

95. Durlacher SH, Banfield WG Jr, Bergner AD (1950) Post-mortem pulmonary edema. Yale J Biol Med 22(6):565-572

96. Vlachaki EM, Koutsopoulos AV, Tzanakis N, Neofytou E, Siganaki M, Drositis I, Moniakis A, Schiza S, Siafakas NM, Tzortzaki EG (2010) Altered surfactant protein-A expression in type II pneumocytes in COPD. Chest 137(1):37-45. https://doi.org/ 10.1378/chest.09-1029

97. Sauvageau A, Boghossian E (2010) Classification of asphyxia: the need for standardization. J Forensic Sci 55(5):1259-1267. https:// doi.org/10.1111/j.1556-4029.2010.01459.x

Publisher's note Springer Nature remains neutral with regard to jurisdictional claims in published maps and institutional affiliations. 